\title{
Solidaritas Sosial Sepuluh Pilar UKM Universitas Muhammadiah Makassar
}

\author{
Andi Asrul AM ${ }^{1}$, Nurdin², Syahban Nur ${ }^{3}$ \\ ${ }^{1}$ Pendidikan Sosiologi, Universitas Muhammadiyah Makassar \\ Email: andiasrul@gmail.ac.id \\ ${ }^{2}$ Pendidikan Sosiologi, Universitas Muhammadiyah Makassar \\ Email: nurdin@unismuh.ac.id \\ ${ }^{3}$ Pendidikan Sosiologi, Universitas Muhammadiyah Makassar \\ Email: syahbannur@unismuh.ac.id
}

\begin{abstract}
This research is a qualitative study that studies case studies that support (i) to describe the activities and patterns of student solidarity among the 10 Pillars of Makassar Unismuh UKM. This study is a member of the 10 pillars of Unismuh Makassar UKM and took samples using a purposive sampling technique by selecting 2 people from each Unismuh Makassar UKM. Data collection methods are observation, interview, participation, and documentation. Data analysis was carried out through the stages of data reduction, presentation of data verification and conclusions. While the validity of the data technique uses triangulation of trigulsion sources, trigulsion techniques and time trigulances. The results showed that social solidarity among members of the 10 Pillars of Unismuh Makassar UKM are (i) forming organic social-mechanical solidarity (ii) Factors that cause mangrove factors as members of the 10 Pillars of Unismuh Makassar SMEs as the basis for developing social solidarity among 10 Members Unismuh Makassar Pillar. The family value inherent in the members of the 10 Pillars of Unismuh Makassar UKM can establish social relationships with other members.
\end{abstract}

Keywords: solidarity, qualitative, organic-mechanical solidarity.

\begin{abstract}
Abstrak. Penelitian ini adalah penelitian kualitatif melalui pendekatan studi kasus yang bertujuan (i) untuk mendeskripsikan kegiatan dan pola solidaritas mahasiswa diantara 10 Pilar UKM Unismuh Makassar Adapun populasi penelitian adalah anggota dari 10 pilar UKM Unismuh Makassar dan pengambilan sampel mengunakan teknik purposive sampling dengan memilih 2 orang dari masing-masing UKM Unismuh Makassar. Metode pengumpulan data adalah observasi, wawancara, partisipasi, dan dokumentasi. Analisis data dilakukan melalui tahapan reduksi data, penyajian data perifikasi dan penarikan kesimpulan. Sedangkan teknik keabsahan data meliputi uji trianggulasi yakni trigulansi sumber, trigulansi teknik dan trigulansi waktu. Hasil penelitian menunjukkan bahwa solidaritas sosial di kalangan anggota 10 Pilar UKM Unismuh Makassar adalah (i) berbentuk solidaritas sosial organik-mekanik (ii) Faktor-faktor ini mangalahkan faktor kesamaan sebagai anggota 10 Pilar UKM Unismuh Makassar sebagai dasar dalam membangun solidaritas sosial di kalangan Anggota 10 Pilar UKM Unismuh Makassar. Nilai kekeluargaan yang melekat pada diri anggota 10 Pilar UKM Unismuh Makassar dapat menjalin hubungan sosial dengan anggota yang lainnya.
\end{abstract}

Kata Kunci: Solidaritas, Kualitatif, Solidaritas Organic-Mekanik.

\section{PENDAHULUAN}

Manusia pada dasarnya adalah makhluk sosial yang memiliki naluri untuk senantiasa hidup dengan orang lain. Naluri manusia untuk selalu hidup dengan orang lain disebut gregariousness sehingga manusia juga disebut sebagai social animal atau hewan sosial. Karena sejak dilahirkan manusia sudah memiliki keinginan pokok yaitu keinginan untuk menjadi satu dengan manusia lain 
disekelilingnya (yaitu masyarakat) dan keinginan untuk menjadi satu dengan suasana alam sekelilingnya.

Sebagai makhluk sosial manusia tidak dapat hidup sendiri tetapi membutuhkan manusia yang lainnya. Dalam menjalani kehidupan antara manusia yang satu dengan yang lain saling membutuhkan untuk memenuhi kebutuhan hidupnya. Untuk terciptanya kehidupan bersama antara manusia maka sangat penting untuk adanya interaksi sosial antara satu dengan yang lain. Interaksi sosial merupakan kunci dari semua kehidupan sosial karena tanpa interaksi sosial, tak akan mungkin ada kehidupan bersama.

Suatu hubungan sosial akan lahir dari interaksi yang senantiasa berjalan dengan baik. Interaksi sosial pada dasarnya adalah hubungan timbal balik antara individu dengan individu, individu dengan kelompok, dan kelompok dengan kelompok. Intinya bahwa dalam proses interaksi ada saling mempengaruhi antara satu dengan yang lain atau (give and take) melalui berbicara atau saling menukar tanda yang dapat menimbulkan perubahan dalam

Perasaan dan kesan dalam pikiran yang selanjutnya menentukan tindakan yang akan kita lakukan. Hal ini dipertegas oleh Roucek dan Warren bahwa interaksi merupakan dasar dari segala proses sosial. Sebagaimana telah dikemukakan diatas bahwa manusia adalah makhluk sosial yang tidak dapat hidup sendiri dan senantiasa membutuhkan manusia lain dalam kehidupannya. Dalam rangkaian perjalanan hidupnya manusia secara alamiah tidak dapat hidup sendiri, manusia senantiasa berinteraksi dengan manusia yang lain sehingga dengan sendirinya manusia telah terlibat dalam kelompok. Didalam kelompok inilah proses sosialisasi berlangsung dan manusia belajar untuk menyesuaikan diri dengan lingkungannya.

Hampir dari seluruh aktivitas manusia dihabiskan melalui interaksi dalam kelompok, belajar dalam kelompok, dan sebagainya. Dengan adanya berbagai kegiatan kelompok tersebut maka manusia menghabiskan seluruh waktunya dalam berbagai keanggotaan dalam kelompok. Dengan demikian dapat dikatakan bahwa dalam setiap perkembangannya manusia membutuhkan kelompok. Hal ini sesuai dengan pandangan Yusmar Yusuf, bahwa kelompok adalah sebagai wadah/wahana manusia untuk melangsungkan hidupnya, karena dengan kelompok manusia dapat memenuhi kebutuhan, dapat mengembangkan diri, mengembangkan potensi serta aktualisasi diri. Pandangan ini bertolak dari pemikiran bahwa manusia merupakan makhluk sosial yang tetap memiliki keinginan untuk bergabung dengan orang lain atau keinginan berkelompok.

Dalam berbagai kelompok sosial dimana manusia menjadi anggota-anggotanya seperti keluarga, organisasi profesi, organisasi kedaerahan, organisasi kemahasiswa-an, dan lain sebagainya, setiap anggotanya saling berinteraksi antara satu dengan yang lain baik melalui komunikasi social maupun kontak sosial. Proses interaksi ini sangat penting untuk mencapai tujuan bersama. Persoalan yang sangat penting dalam kehidupan berkelompok agar tetap menjaga eksistensi sebuah kelompok adalah bagaimana solidaritas sosial yang terbangun diantara anggota kelompok tersebut sebagai suatu keseluruhan. Dalam kelompok harus muncul kesadaran kolektif sebagai anggota kelompok sehingga antara sesama anggota kelompok tumbuh perasaan-perasaan atau sentiment atas dasar kesamaan sehingga dapat tercipta rasa solidaritas sosial dan bisa mencapai tujuan bersama dalam organisasi.

Dikalangan mahasiswa juga sangat dibutuhkan solidaritas antar mahasiswa dan masyarakat pelajar lainnya. Dimana hal ini dipersiapkan jauh sebelum mahasiswa terjun langsung ketengahtengah masyarakat. Tentunya dengan pemahaman yang baik tentang solidaritas social ini mahasiswa diharapkan mampu berperan lebih sebagai kaum intelektual, Karena begitulah banyak diajarkan di Unismuh Makassar dalam mengamalkan amal ma'ruf nahimungkar.

Unismuh Makassar didirikan pada tanggal 19 juni 1963 sebagai cabang dari Universitas Muhammadiyah Jakarta. Pendirian perguruan tinggi ini adalah sebagai realisasi dari hasil Musyawarah Wilayah Sulawesi Selatan dan Tenggara ke-21 di Kabupaten Bantaeng. Pendirian tersebut didukung oleh Persyarikatan Muhammadiyah sebagai organisasi yang bergerak dibidang pendidikan dan pengajaran dakwah amar ma'ruf nahi mungkar, lewat surat nomor: E-61098/1963 
tertanggal 22 jumadil Akhir 1394/12 juli 1963 M. Kemudian akte pendiriannya dibuat oleh notaries R. Sinijo berdasarkan akta notaris Nomor : 71 tanggal 19 juni 1963.

Kampus Unismuh Makassar juga membina berbagai lembaga sebagai wadah kreatifitas dan pengembangan sumberdaya mahasiswa sesuai dengan minat dan bakat baik ditingkat Universitas, tingkat fakultas, sampai ketingkat program studi.Unit Kegiatan Mahasiswa (UKM) adalah lembaga yang dibentuk sebagai wadah pembianaan kegiatan tertentu yang diminati mahasiswa dan sesuai dengan misi Unismuh Makassar. (Pasal 9 : poin 1, Pola umum pembinaan kemahasiswaan) UKM merupakan lembaga intra otonom yang artinya lembaga ini berjalan sesuai dengan bidang yang dikembangkan masing-masing anggotanya, serta sistem anggaran dasar dan anggaran rumah tangganya di buat sesuai kebutuhan lembaganya masing-masing dan disesuaikan dengan kaidah perguruan tinggi dan statuta muhammadiyah yang dirumuskan dalam musyawarah/sidang-sidang ditiap-tiap UKM itu sendiri.

Di Unismuh Makassar ada 10 UKM yaitu, UKM HW bergerak di bidang kepanduan, UKM Tapak suci bergerak di bidang seni bela diri., UKM LKIM PENA bergerak di bidang karya tulis dan penelitian, UKM Seni \& budaya TALAS bergerak di bidang seni dan budaya, UKM Corong bergerak di bidang peliputan dan pemberitaan, UKM KSR-PMI Unit 114 bergerak dibidang kemanusian dan medis, UKM olahraga bergerak di bidang olahraga, UKM Pahala bergerak di bidang pemerhatian alam dan lingkungan hidup, UKM PS Unismuh bergerak di bidang sepak bola, dan UKM Bahasa bergerak di bidang bahasa

10 Pilar UKM Unismuh Makassar ini sendiri mulai dikenal pada tahun 2013 yang pada saat itu masih terhitung 9 Pilar UKM Unismuh Makassar, sebelum 9 Pilar UKM Unismuh Makassar dikenal, sudah terjalin kerjasama antar UKM yang pada saat itu dikenal dengan nama Aliansi UKM yang terdiri dari 8 UKM, alasan lahirnya Aliansi sebenarnya juga terlahir dari adanya tujuan yang sama antar UKM. Meski belum terlalu solid pada saat itu karna beberapa garis sejarah dan banyaknya perbedaan diantara lembaga tertentu.

Alasan peneliti memilih judul di atas sebagai yaitu, Sebagai peneliti saya ingin mengetahui dasar dan alasan mengapa UKM Unismuh Makassar bisa Solid yang pada dasarnya UKM-UKM tersebut penuh dengan dasar, tujuan dan bidang yang berbeda, Sebagai bagian dari salah satu Lembanga yang ada di Unismuh Makassar yaitu BEM FKIP Unismuh Makassar penulis ingin meneliti agar sekiranya hasil penelitian ini bisa dijadikan referensi dikemudian hari dalam menjaga dan membangun solidaritas mahasiswa UKM Unismuh Makassar khusunya dan seluruh lembaga kampus Unismuh Makassar pada dan Menjadikan hasil penelitian sebagai inspirator dan inisiator untuk menjalankan tugas-tugas kelembagaan tanpa harus melalaikan solidaritas.

\section{METODE PENELITIAN}

Jenis penelitian ini adalah kualitatif melalui pendekatan studi kasus dilaksanakan pada bulan Mei-Juni 2018 yang bertempat di kampus Unismuh Makassar. Instrument penelitian ini adalah peneliti sendiri (human instrument) dengan menggunakan alat bantu berupa pedoman wawancara, instrument dokumentasi dan catatn observasi, alat perekam dan kamera. Pemilihan informan dengan cara purposive sampling dengan memilih 2 orang dari masing-masing UKM Unismuh Makassar. Adapun status keanggotaan dalam tiap-tiap lembaga UKM berbeda-beda dan untuk memilih informan maka peneliti hanya akan memilih satu dari pengurus yang menjabat dalam hal ini ketua masing-masing tiap lembaga dan satu lagi anggota muda atau baru dari masing-masing UKM. Proses dipilihnya juga berdasarkan kapabilitas dan pengalaman dari anggota tersebut. Fokus penelitian solidaritas sosial sepuluh pilar ukm UNISMUH. Teknik pengumpulan data menggunakan metode observasi, wawancara, partisipatif, dan dokumentasi. Analisis data dilakukan melalui tahapan reduksi data (data reduction), penyajian data (display data) verivication dan penarikan kesimpulan. Sedangkan teknik keabsahan data meliputi uji trianggulasi yakni trigulansi sumber, trigulansi teknik dan trigulansi waktu. 


\section{HASIL DAN PEMBAHASAN}

\section{a. Solidaritas Sosial 10 Pilar UKM Unismuh Makassar}

Dalam setiap kehidupan bersama, solidaritas sosial diantara orang-orang yang hidup bersama itu sangat dibutuhkan. Adanya solidaritas sosial diantara anggota kelompok akan melahirkan kesadaran kolektif diantara mereka. Solidaritas sosial sendiri sebagaimana dikemukakan oleh Paul Jonhson (1986:181) diartikan sebagai satu keadaan hubungan antar individu dan/atau kelompok yang di UKM perasaan moral dan kepercayaan yang dianut bersama yang diperkuat oleh pengalaman emosional bersama. Apabila dalam kelompok tersebut terjalin solidaritas sosial diantara anggotanya maka akan tercipta iklim yang mendorong pencapaian tujuan kelompok.

Dalam perspektif sosiologi, keakraban hubungan antara kelompok masyarakat itu tidak hanya merupakan alat dalam rangka usaha mencapai atau untuk mewujudkan cita-citanya, akan tetapi justru keakraban hubungan social tersebut sekaligus merupakan salah satu tujuan utama dari kehidupan kelompok masyarakat. Keadaan kelompok yang semakin kokoh selanjutnya akan menimbulkan sense ofbelongingness diantara anggotanya.

10 Pilar UKM Unismuh Makassar merupakan unit kegiatan mahasiswa yang menjadi wadah untuk mengembangkan potensi yang di maliki oleh mahasiswa, untuk mengetahui lebih lanjut tentang bentuk-bentuk solidaritas dan faktor-faktor yang menyebabkan terjadinya solidaritas sosial maka penulis melakukan observasi atau pengamatan dan melakukan wawancara mendalam berikut hasil wawancara yang telah di lakukan oleh penulis terhadap informan:

\section{M.A.S}

Ketika penulis memulai wawancara dan menanyakan bagaimana hubungan emosional terhadap sesama anggota UKM yang terjalin selama ini. M.A.S menuturkan bahwa hubungan sesama anggota selama ini baik-baik saja itu di sebabkan karena masing-masing anggota paham dan bisa saling mengerti satu dengan yang lainnya, M.A.S juga menjelaskan bahwa hubungan sesama anggota itu lumayan dekat karena kita semua sadar bahwa kita satu kesatuan meski warna dan tujuan lembaga kita berbeda namun kita satu karna Unit Kegiatan Mahasiswa, meskipun banyak perbedaan di mulai dari beda fakultas, beda daerah dan beda UKM.

M.A.S "Meskipun tidak bisa dipungkiri kita terkadang juga biasa berlomba-lomba membawa bendera kita agar bisa lebih berkibar namun untuk saling mendukung dan saling membantu tetaplah kita kedepankan sebab kita merasa punya nasib dan keberadaan yang sama serta tugas yang sama meski ruang lingkup kita berbeda yakni mengharumkan nama baik almamater kampus."

M.A.S melanjutkan penjelasannya pada da UKM nya hubungan sesama UKM itu berjalan dengan cukup harmonis itu dida UKM $\mathrm{i}$ hubungan kekerabatan antar anggota UKM dan saling menghargai satu sama yang lain dan menyampingkan perbedaan-perbedaan dan saling melengkapi satu sama yang lain serta duduk bersama sebagai pembuktian kekerabatan, bisa saling menerima dan berbagi pengalaman. Kemudian penulis bertanya tentang konflik yang pernah terjadi di UKM dan bagaimana cara penyelesaiannya, M.A.S langsung menjawab konflik pasti ada di setiap organisasi, begitu halnya di UKM Unismuh Makassar masih saja ada konflik baik sifatnya internal maupun eksternal organisasi masing-masing apalagi melihat perbedaan-perbedaan yang nyata.

\section{2. $\mathrm{Ar}$}

Ketika penulis bertanya tentang apa yang melatarbelangi anda masuk di UKM Pahala, lalu Ar mengatakan bahwa dia masuk karna hobbi dan mengembangkan hobbi tersebut. Kemudian penulis bertanya lagi mengenai hubungan interaksi yang terjalin di UKM Pahala umumnya dan 10 Pilar UKM Khususnya, dia mengatakan dengan nada yang tinggi bahwa hubungan emosional di internal UKM Pahala pada da UKM nya terbangun karna asas kekeluargaan dan tentukan dengan asas itu 
terbangun interaksi dan kerjasama yang baik. Dan hubungan antar sesame UKM sampai hari ini saya pikir berjalan cukup harmonis itu sebabkan oleh rasa sepenanggungan dan persaudaraan yang baik. Ar juga menuturkan keharmonisan itu terwujud semua di karenakan kerjasama, saling menghargai itu tetap terjaga selama ini. Kemudian Ar memperjelas tentang solidaritas bahwa

"Solidaritas itu tidak bisa terbangun tanpa adanya kerjasama" (wawancara Juli 2017)

Penulis lalu bertanya mengeni konflik yang pernah terjadi di antara sesama 10 Pilar UKM Unismuh Makassar kemudian Ar menjelaskan bahwa konflik di setiap organisasi itu pasti ada itu adalah sebuah dinamika dari sebuah lembaga, cumin tergantung kita dan masing-masing lembaga menyikapi dan menindaki masalah tersebut, dan jika ada masalah yang melibatkan 10 Pilar UKM Unismuh Makassar maka langkah awal kita adalah mengkomunikasikan, mengkoordinasikan antar sesame dulu baru berfikir bersama bagaimana menindaki masalah tersebut.

"Kita adalah satu kesatuan meskipun beda orientasi lembaga setidaknya kita sadar keberadaannya kita dan keberadaannya mereka, dan intinya tetap saling mendukung satu sama lain dan kerjasama yang baik, serta komunikasi dan koordinasi di permantap". (wawancara $8 \mathrm{JULI}$ 2017)

3. $\mathrm{XXX}$

Ketika penulis menanyakan bagaimana hubungan solidaritas antar anggota 10 Pilar UKM dia kemudian menjelaskan tentang kedekatannya antar anggota 10 Pilar UKM Unismuh Makassar .

A.H "Hubungan yang terjalin di UKM cukup baik, itu di sebabkan karena kita berada dilingkungan yang sama dan hamper ketemu setiap hari, hal ini membuat kita bias saling mengenal dengan baik meskipun masih ada beberapa yang tidak begitu terlalu akrab. Akan tetapi saat kita bekerja di ruang lingkup yang sama kita bias dengan mudah menyesuakan diri dengan anggota UKM yang laindan dapat terjalin bekerjasama baik". (wawancara 10 JULI 2017)

A.H memberikan contoh sedikit proses kegiatan kita setiap tahunnya mengenai penerimaan mahasiswa baru yang diadakan tiap tahunnya saat kita mempunyai tugas yang sama kita bias dengan mudahnya langsung berbaur dan bias saling membantu karna kita sudah terbiasa tatap muka sebelumnya, kita mungkin sadar bahwa terkadang kita punya masalah lembaga tersendiri termasuk berbagai perbedaan-perbedaan dan biasa terlibat beberapa anggota dalam konflik lembaga seperti konflik lembaga di masa lalu ataukah masalah-masalah konflik yang lain namun teman-teman di UKM masing-masing lebih menekankan kepada professional dan dewasa dalam berlembaga.

"Ada titik dimana kita tidak ingin lagi terjadi konflik. Konflik itu sendiri sebenarnya juga ada positifnya. Konflik itu melahirkan perubahan social dalam suatu sistem. Negatifnya sendiri dapat menghancurkan jalinan kerjasama dalam suatu kelompok" (wawancara, 10 JULI 2017)

\section{4. $\mathrm{XXX}$}

Pertama-tama penulis menanyakan mengenai kondisi sekarang yang terjadi di 10 Pilar UKM Unismuh Makassar itu seperta apa,kemudian penulis menjawab bahwa ada yang hilang sebenarnya selama ini di 10 Pilar UKM Unismuh Makassar sebuah budaya yang mulai terkikis secara perlahanlahan di mulai dari budaya semangat berorganisasi yang sudah mulai berkurang seakan-akan organisasi cuman tempat persinggahan bukan tempat sebagai proses pembelajaran itulah semua yang mengakibatkan organisasi masih stagnan padahal kalau kita berpikir ini organisasi yang be UKM dan sudah berumur 26 tahun lamanya.budaya malas kesadaran yang kurang akan tanggung jawabnya merupakan budaya yang harus di hilangkan sebenarnya J.S membandingkan dari kepengurusan kepengurusan sebelumnya memberikan contoh 5 tahun yang lalu dimana seniorsenior saat sanagt berjuang dengan keras untuk mengembangkan organisasi ini.kemudian penulis menyakan hubungan solidaritas yang terjalin saat ini di 10 Pilar UKM Unismuh Makassar seperti apa,J.S mengatakan untuk hubungan anggota sebenarnya baik-baik saja semuanya berjalan dengan 
baik saja bisa di katakan solidaritas sesama anggota masih bagus,tetapi yang kurang saat ini semenjak saya berada selama 3 tahun itu adalah kurangnya kesadaran anggota dalam mengembangkan kemampuan manajemen berorganisasi maupn kemampuan dalam pemantapan skill anggota. J.S menjelaskan bahwa organisasi ini membutuhkan orang-orang yang loyal,orangorang memiliki integritas yang tinggi tahu akan tanggung jawabnya sebagai yang tiap saat bisa menolong sesama,kemampuan atau skill yang harus di kembangkan tetapi kenyataan yang saya lihat sekarang tidak begitu, anggota kurang sekali latihan-latihan dalam peningkatan skill.aturan-aturan yang sudah di tetapkan oleh badan pengurus itu sudah banyak yang di langgar contoh kecil saja di larangnya anggota untuk masuk dalam ruang badan pengurus dan ruang peralatan tapi sampai saat ini masih banyak saja anggota yang melanggarnya.inilah yang saya katakan.

"Budaya-budaya malas seperti inilah yang harus di buang jauh-jauh,bagaimana mau menumbuhkan rasa lolidaritas anggota kalau tidak adanya kesadaran yang di miliki angota itu sendiri kerjasaama tidak bisa terjalin tanpa adanya saling menghargai kepada sesame" (wawancara 11 JULI 2017)

J.S yang saat ini menjabat sebagai ketua 10 Pilar UKM Unismuh Makassar memfokuskan tahun ini kembali peningkatan solidaritas anggota dengan cara membuat kegiatankegiatan pelatihanpelatihan demi peningkatan skill anggota dan menjalin lagi keakraban sesama anggota dengan cara itulah solidaritas anggota bias terwujud. penulis menanyakan mengenai konflik yang pernah terjadi di 10 Pilar UKM Unismuh Makassar, J.S mengatakan bahwa pada da UKM nya konflik di 10 Pilar UKM Unismuh Makassar itu sangat jarang ada kalaupun ada mungkin secara personal saja seperti kepengurusan tahun lalu dimana ketuanya banyak anggota yang tidak senang atas kepemimpinannya boleh di katakana sangat otoriter dan juga sangat tertutup,tidak bisa merangkul dan mengajak kembali anggota bekerjasama dengan baik dapat kita lihat dampak semuanya itu kepengurusan tahun lalu boleh di katakana hancur tidak ada perkembangan sama sekali.komunikasi badan pengurus dan anggota itu berjalan dengan baik.

\section{PEMBAHASAN}

\section{A. Solidaritas Sosial Dalam Perspektif Emile Durkheim}

Melihat kondisi solidaritas dan berdasarkan observasi, serta wawancara dengan pihak-pihak terkait. Peneliti memilih teori Solidaritas Emile Durkhei, teori ini dianggap relevan dalam penelitian tentang Pola Solidaritas Mahasiswa diantara 10 Pilar UKM Unismuh Makassar, teori ini sesuai dengan penelitian yang dilakukan oleh peneliti. Dalam teori solidaritas ini yang lebih ditekan oleh peneliti adalah solidaritas dalam bentuk Mekanis, karena adanya perbedaan dalam bidang masingmasing yang dilakukan oleh mahasiswa. Meskipun sama-sama tergabung dalam UKM akan tetapi unit kegiatan yang berbeda-beda, ini membuat peneliti tertari pada pola solidaritas yang terjalin antara mereka.

Dari pemaparan yang telah dikemukakan oleh informan diatas, maka dapat diperoleh gambaran mengenai bentuk solidaritas social yang terjadi di kalangan anggota 10 Pilar UKM Unismuh Makassar. Gambaran tersebut akan dibagi menjadi solidaritas mekanik dan solidaritas organik sebagaimana yang dilakukan oleh Emile Durkheim.

\section{Solidaritas Mekanik}

Solidaritas Mekanik adalah solidaritas yang muncul pada masyarakat yang masih sederhana dan diikat oleh kesadaran kolektif serta belum mengenal adanya pembagian kerja diantara para anggota kelompok. (Masyarakat Pedesaan).

a. Nilai-nilai kekeluargaan sebagai sebuah nilai yang dianggap sakral bagi anggota 10 Pilar UKM Unismuh Makassar. dianggap dapat menyatukan mereka sebagai sesama anggota UKM. Meskipun belum terinternalisasi dalam diri anggota UKM secara umum. 
b. Anggota 10 Pilar UKM Unismuh Makassar tetap membaur dan tetap saling kerjasama itu terlihat ketika 10 Pilar UKM Unismuh Makassar mempunyai kegiatan, pekerjaan di lakukan secara kolektif dan penuh tanggung jawab itulah betapa kuatnya rasa kebersamaan yang di miliki sesama anggota.

\section{Solidaritas organic}

Solidaritas Organik adalah solidaritas yang mengikat masyarakat yang sudah kompleks dan telah mengenal pembagian kerja yang teratur sehingga disatukan oleh saling ketergantungan antar anggota. (Masyarakat Perkotaan)

a. Pembagian kerja (tugas) dilakukan dalam bentuk kepanitiaan. Warga dalam melaksanakan tugas atau pekerjaan dida UKM kan atas surat keputusan yang dikeluarkan oleh Badan Pengurus 10 Pilar UKM Unismuh Makassar Kecenderungan yang terjadi adalah warga baru akan terlibat dalam kegiatan apabila namanya masuk sebagai panitia. Bahkan ada juga yang nama tercantum dalam SK, tetapi tidak ikut berpartisipasi dalam kepanitiaan.

b. Kesadaran individu kurang. Kondisi ini dapat dilihat masih adanya beberapa anggota yang tidak sadar akan tanggung jawabnya sebagai anggota,contohnya saja masih adanya anggota yang selalu melanggar tata tertib yang di perlakukan di posko 10 Pilar UKM Unismuh Makassar. Orang-orang yang seperti inilah susah akan di ajak kerjasama dalam beroganisasi.

c. Apabila ada anggota yang melakukan pelanggaran maka akan di lakukan rapat internal anggota dan akan di selesaikan secara kekelurgaan,dan kalaupun tidak bisa di selesaikan secara kekelurgaan makan akan di kenakan sanksi sesuai dengan aturan yang berlaku.

d. Anggota 10 Pilar UKM Unismuh Makassar secara umum saling tergantung satu dengan yang lain. Dalam kepanitiaan misalnya, panitia tidak bisa menjalankan sendiri kepanitiaan tetapi membutuhkan panitia pengarah yang biasanya disebut stering komitie diambil dari anggota yang lebih senior atau yang telah berpengalaman. Demikian pula dalam kepengurusan, pengurus tidak bisa berdiri sendiri tetapi membutuhkan warga yang lain untuk melaksanakan program kerja yang telah dirumuskan. Selain itu ada pula badan pertimbangan organisasi yang menjadi tempat konsultasi bagi pengurus. Jadi setidaknya, dalam satu periode kepengurusan sesame anggotakan saling membutuhkan satu dengan yang lain dalam menjalankan kegiatan di UKM. Meskipun dalam kenyataannya hal ini masih belum dipahami secara baik.

e. Apabila ada warga yang melakukan pelanggaran maka ada mekanisme penjatuhan sanksi. Warga tidak langsung menghakimi sesama anggota mungkin berupa teguran dan peringatan dan akan di bahas secara kekeluargaan dalam rapat internal anggota atau biasa di sebut De Brefing semacam evaluasi dari kegiatan pelaksanaan yang kita telah lakukan.

f. Anggota 10 Pilar UKM Unismuh Makassar sangat heterogen. Sangat banyak keberagaman melebur di dalam 10 Pilar UKM Unismuh Makassar . Perbedaan fakultas,jurusan, angkatan, asal daerah, suku, jenis kelamin, agama, asal sekolah, strata sosial dan ekonomi, dan sebagainya. Perbedaan inilah yang membuat solidaritas social yang di miliki sesame anggota UKM itu sangat kuat karena denagn tujuan yang sama yaitu kemanusian dan pengabdian kepada masyarakat.

g. Solidaritas organik dapat pula di wujudkan dalam bentuk saling tolong menolong antar sesama anggota , itu terlihat adanya suatu kegiatan operasi dan siaga yang menjadi tugas pokok dari 10 Pilar UKM Unismuh Makassar itu sendiri,sebagian di ungkapan oleh anggota atau responden yang memberikan keterangan tentang hal itu.

Solidaritas sosial di kalangan anggota 10 Pilar UKM Unismuh Makassar berbentuk solidaritas sosial organik-mekanik. Artinya bahwa dikalangan anggota 10 Pilar UKM Unismuh Makassar, bentuk solidaritas yang terbangun adalah solidaritas mekanik.solidaritas mekanik diwujudkan dalam hubungan sesama anggota itu di wujudkan dalam kehidupan sehari-hari Namun, adapula terbangun solidaritas organic dimana bisa di wujudkan dalam saling tolong menolong baik dalam melakukan tugas kemanusian ataupun di kehidupan sehari-hari. Dikatakan solidaritas sosial organik-mekanik karena anggota 10 Pilar UKM Unismuh Makassar sangat beragam terutama berbeda dari segi fakultas, jurusan, angkatan, agama, suku dan sebagainya. Solidaritas sosial sebagai anggota 10 Pilar 
UKM Unismuh Makassar sangatlah terbangun dengan baik itu semua terlihat dari pernyataan yang di sampaikan oleh anggota UKM itu sendiri.

\section{Faktor-faktor yang mendasari 10 pilar UKM UNISMUH}

Faktor-faktor yang menjadi dasar solidaritas sosial di kalangan anggota 10 Pilar UKM Unismuh Makassar yaitu satu angkatan,tujuan yang sama yaitu ingin menolong kepada sesame terus kesamaan minat hobby terhadap kegiatan-kegiatan alam bebassebagai sesame anggota 10 Pilar UKM Unismuh Makassar. Faktor-faktor ini mangalahkan faktor kesamaan sebagai anggota 10 Pilar UKM Unismuh Makassar sebagai dasar dalam membangun solidaritas sosial di kalangan Anggota 10 Pilar UKM Unismuh Makassar. Nilai kekeluargaan yang melekat pada diri anggota 10 Pilar UKM Unismuh Makassar dapat menjalin hubungan sosial dengan anggota yang lainnya. Kondisi ini sangat jelas terlihat hubungan emosional anggota sangat terjalin begitu dengan erat,kerjasama yang kuat baik di didalam organisasi maupun di luar organisasi,mampu menciptakan sebuah keharmonisan dalam keluarga itu di tandai adanya kegiatan minggu seperti futsal,arisan, masak-memasak dan masih banyak yang lainnya yang dapat membuat akrab sesame anggota satu sama lain.ini sanagt jarang di dapat di organisasi lain kecuali di 10 Pilar UKM Unismuh Makassar yang bermukim di pusat kegiatan mahasiswa universitas hasanuddin.

\section{KESIMPULAN}

Solidaritas sosial di kalangan anggota 10 Pilar UKM Unismuh Makassar adalah (i) berbentuk solidaritas sosial organik-mekanik (ii) Faktor-faktor ini mangalahkan faktor kesamaan sebagai anggota 10 Pilar UKM Unismuh Makassar sebagai dasar dalam membangun solidaritas sosial di kalangan Anggota 10 Pilar UKM Unismuh Makassar. Nilai kekeluargaan yang melekat pada diri anggota 10 Pilar UKM Unismuh Makassar dapat menjalin hubungan sosial dengan anggota yang lainnya.

\section{DAFTAR PUSTAKA}

Bungin, Burhan. 2008. Sosiologi Komunikasi. Jakarta: Kencana.

B. Simanjuntak dan Chidir Alie. 1970. Kriminologi. Bandung.

Campbell, Tom. 1994. Tujuh Teori Sosial. Yogyakarta: Kanisius.

Cohen, Bruce J. 1992. Sosiologi Suatu Pengantar. Diindonesiakan oleh Sahat Simumora.Jakarta:

Rineka Cipta.

Franz Magnis Suseno, Filsafat Sebagai Ilmu Kritis (Yogyakarta: Kanisius,1991), hal. 230.

Faisal, Sanapiah. 2005. Format-Format Penelitian Sosial. Jakarta. PT Raja Grafindo Persada.

Gedungan. W. A. 1983. Psyichologi Sosial. Eresco : Bandung.

George Ritzer, Teori Sosiologi Modern (Jakarta: kencana, 2005 ), hal. 24

Huraerah, Abu dan Purwanto. 2006. Dinamika Kelompok Konsep dan Aplikasi. Jakarta: Refika Aditama.

Moleong, Lexy. 1990. Metode Penelitian Kualitatif. Remaja Roesdakarya :Bandung.

Moleong, Lexy J. 2008. Metodologi Penelitian Kualitatif. Bandung: ROSDA

Narwoko, J Dwi dan Suyanto, Bagong. 2007. Sosiologi Teks Pengantar dan Terapan. Jakarta: Kencana.

Polak. Mayor. 1974. Sosiologi, Pengantar Ringkas. Ikhtisar Baru : Jakarta.

Soedijati, Elisabeth, Koes. 1995. Solidaritas dan Masalah Sosial Kelompok Waria. Bandung: UPPM STIE Bandung.

Soekanto Soerjono. 1970. Sosiologi Suatu Pengantar. Jakarta.

, Soerjono.2010. Pengantar Sosiologi Kelompok. Bandung: Remadja Karya.

Sugiyono, 2008. Metode Penelitian Kuantitatif, Kualitatif, dan R\&D. Bandung: Alfabeta.

Syani, Abdul.2007. Sosiologi Skematika,Teori, dan Terapan. Jakarta: Bumi Aksara.

Vegeer. K. J. 1986. Realitas Sosial. PT. Gramedia : Jakarta.

Vrendenbergt. 1984. Metode Penelitian Masyarakat kampus. PT. Gramedia : Jakarta. 